\title{
FGF binding by extracellular matrix components of Wharton's jelly
}

\author{
Andrzej Malkowski ${ }^{1}$, Krzysztof Sobolewski ${ }^{1}$, Stefan Jaworski ${ }^{2}$ and \\ Edward Bankowski ${ }^{1 \bowtie}$ \\ ${ }^{1}$ Department of Medical Biochemistry, and ${ }^{2}$ Department of Gynaecology, Medical Academy of Bialystok, \\ Biatystok, Poland
}

Received: 14 November, 2006; revised: 27 March, 2007; accepted: 23 May, 2007 available on-line: 12 June, 2007

\begin{abstract}
Our earlier paper has reported that Wharton's jelly is a reservoir of several peptide growth factors, including acidic and basic fibroblast growth factors (aFGF and bFGF, respectively). Both can be extracted by buffered salts solutions in the form of high molecular mass complexes, probably with a component(s) of the extracellular matrix. Both aFGF and bFGF from such extracts hardly penetrate $10 \%$ polyacrylamide gels during electrophoresis. Pre-treatment of Wharton's jelly with hyaluronidase slightly increased the extractability of aFGF, but did not affect the extractability of bFGF. In contrast, the pre-treatment of tissue homogenate with bacterial collagenase ( $2000 \mathrm{U} /$ $\mathrm{ml}, 37^{\circ} \mathrm{C}, 18 \mathrm{~h}$ ) increased the extractability of bFGF. The presence of $\beta$-mercaptoethanol in the extracting solutions increased the extractability of both FGFs, but did not release FGFs in their free form, despite reducing the molecular mass of the FGF-containing complexes. We conclude that both aFGF and bFGF are bound through disulphide bonds to a protein component of Wharton's jelly. We propose that ground substance composed mainly of collagen fibrils and hyaluronate molecules, which surrounds the cells of Wharton's jelly, prevents the access of the extracting solution to aFGF and bFGF. Although hyaluronate and collagen do not bind aFGF or bFGF directly, they may constitute a barrier which prevents the dispersion of FGFs in Wharton's jelly. Thus, the high concentration of FGFs around the cells of Wharton's jelly may facilitate the interaction of these factors with membrane receptors, thereby resulting in stimulation of cell division and differentiation, as well as of the synthesis of extracellular matrix components.
\end{abstract}

Keywords: fibroblast growth factor, umbilical cord, metalloproteinases

\section{INTRODUCTION}

The umbilical cord forms the connection between the placenta and the fetus. It contains one vein and two arteries surrounded by a myxomatous substance called Wharton's jelly, consisting of a very low number of cells and high amounts of extracellular matrix (ECM) components, mainly collagen, hyaluronate and several sulphated proteoglycans (Sobolewski et al., 1997; Franc et al., 1998). The high amount of hyaluronic acid makes this tissue highly hydrated and the collagen content makes it resistant to extension and compression evoked by foetal movements and uterine contraction.

It is well known that biosynthesis of extracellular matrix components is enhanced by several peptide growth factors, especially insulin-like growth factor-I (IGF-I) (Edmondson et al., 2003), fibroblast growth factor (FGF) (Yu et al., 2003) and transforming growth factor $\beta$ (TGF- $\beta$ ) (Shalitin et al., 2003).

FGFs are a group of cytokines which play major regulatory roles in development, wound heal-

$\triangle$ Corresponding author: E. Bańkowski, Department of Medical Biochemistry, Medical Academy of Bialystok, A. Mickiewicza 2C, 15-089 Białystok, Poland; phone: (48 85) 748 5578; fax: (48 85) 748 5578; e-mail: edward12@amb.edu.pl Abbreviations: aFGF, acidic fibroblast growth factor; APMA, amino-phenylomercuric acetate; bFGF, basic fibroblast growth factor; ECM, extracellular matrix; EGF, epidermal growth factor; IGF-I, insulin-like growth factor I; MMP, matrix metalloproteinase; PDGF, platelet-derived growth factor; TBS, Tris-buffered saline; TGF- $\beta$, transforming growth factor $\beta$. 
ing, haematopoiesis and tumourgenesis. To date at least 22 FGFs have been identified in vertebrate tissues. Two of them, viz. acidic FGF (aFGF) and basic FGF (bFGF), with molecular masses of $18-19 \mathrm{kDa}$, are well characterised and important in human tissues. They modulate cellular functions through four distinct high-affinity membrane receptors with an intrinsic tyrosine kinase activity (Ornitz \& Itoh, 2001).

Our previous paper (Sobolewski et al., 2005) reported that Wharton's jelly is a reservoir of many peptide growth factors, such as epidermal growth factor (EGF), platelet-derived growth factor (PDGF), $a F G F, b F G F$, IGF-I and TGF- $\beta$. Since the number of cells in Wharton's jelly is very low and the amount of ECM components is very high, it would seem that such cells are strongly stimulated by peptide growth factors to produce large amounts of collagen and glycosaminoglycans. The FGFs probably belong to the most important stimulators of these processes (Yu et al., 2003).

The cells of Wharton's jelly were previously described as myofibroblasts (Takechi et al., 1993; Kobayashi et al., 1998), with ultrastructural characteristics of both fibroblasts and smooth muscle cells. They may function in both fibrogenesis and contraction, and recent papers (Mitchell et al., 2003; Weiss et al., 2003; Wang et al., 2004) report that some stromal cells have properties of potentially multipotent stem cells. As with other stem cells they contain two specific markers: telomerase - an enzyme which allows them to replicate the telomeres during the $S$ phase of mitosis, and the stem cell factor receptor - termed c-kit (CD117). In response to bFGF they change their phenotype into neuron-like cells or glia cells, and may be xenotransplanted into the brain without immunosuppression therapy (Weiss et al., 2003). It therefore seems that the accumulation of FGFs in Wharton's jelly plays an important role in the physiological functions of stem cells. In this report we evaluate the mechanism of FGF binding by extracellular matrix components of Wharton's jelly.

\section{MATERIALS AND METHODS}

Reagents. Hyaluronidase (type III, EC 3.22.1.35) H 2251 Sigma, collagenase (type VII, EC 3.4.24.3) C 0773 Sigma, heparinase III (EC 4.2.2.8) H 8891 Sigma, chondroitinase ABC (EC 4.2.2.4) C 2905 Sigma, $\beta$-mercaptoethanol M 7154 Sigma, anti-human acidic FGF antibody MAB232 R\&D Systems Inc, anti-human basic FGF antibody MAB233 R\&D Systems Inc, anti-human FGF-receptor 1 (R1) antibody MAB658 R\&D Systems Inc, Quantikine ${ }^{\circledR}$, human acidic FGF immunoassay DFA00B R\&D Systems Inc, Quantikine $^{\circledR}$, human basic FGF immunoassay DFB50 R\&D Systems Inc.
Tissue material. Studies were performed on umbilical cords (UCs) of 10 newborns of the mean body mass $3.668 \pm 371 \mathrm{~g}$, delivered by healthy mothers (without any symptoms of pregnancy-associated pathology), between 38 and 41 weeks of gestation. In all cases, $20 \mathrm{~cm}$ long sections of the umbilical cord were excised beginning from their placental side and Wharton's jelly was carefully separated.

Preparation of tissue homogenates. Samples $(600 \mathrm{mg})$ of tissue were suspended in $6 \mathrm{ml}$ of buffered solution (composition shown below) and homogenised with the use of a knife homogeniser (20000 r.p.m., $2 \times 30 \mathrm{~s}$, at $4^{\circ} \mathrm{C}$ ) and then submitted to ultrasonification $\left(20 \mathrm{kHz}, 3 \times 10 \mathrm{~s}\right.$, at $\left.4^{\circ} \mathrm{C}\right)$. In order to prevent degradation or processing of aFGF and bFGF, a mixture of proteolytic enzyme inhibitors was applied. It consisted of $10 \mathrm{mM}$ 6-aminohexanoic acid + $10 \mathrm{mM}$ EDTA + $10 \mathrm{mM}$ benzaminide $+5 \mathrm{mM}$ $N$-ethylmaleimide $+1 \mathrm{mM}$ phenylmethylsulfonyl fluoride. The homogenates A, B, C and D were prepared in various buffered solutions to provide optimal environments for the action of hyaluronidase (A), collagenase (B), heparinase (C) and chondroitinase (D).

Homogenate A was prepared in $100 \mathrm{mM}$ acetate $+30 \mathrm{mM} \mathrm{NaCl}, \mathrm{pH} 4.0$ (optimal for hyaluronidase action). Homogenate $\mathrm{B}$ was prepared in 50 $\mathrm{mM}$ Tris/ $\mathrm{HCl}+8 \mathrm{mM} \mathrm{CaCl}_{2}$, $\mathrm{pH} 7.4$ (optimal for collagenase action). Homogenate $\mathrm{C}$ was prepared in $50 \mathrm{mM}$ Tris/ $\mathrm{HCl}+1 \mathrm{mM} \mathrm{CaCl}_{2}$, $\mathrm{pH} 7.6$ (optimal for heparinase action). Homogenate $\mathrm{D}$ was prepared in $50 \mathrm{mM}$ Tris/ $\mathrm{HCl}+60 \mathrm{mM}$ sodium acetate, $\mathrm{pH} 8$ (optimal for chondroitinase $\mathrm{ABC}$ action).

Extraction of aFGF and bFGF from tissue homogenates. Each homogenate was divided into three equal parts. One was used as a control, the second was supplemented with $\beta$-mercaptoethanol to a final concentration of $5 \%$, and the third was supplemented with the appropriate hydrolytic enzyme relative to the amount of their substrates in Wharton's jelly (Sobolewski et al., 1997). Thus, homogenate A was supplemented with hyaluronidase $(2000 \mathrm{U} / \mathrm{ml})$, homogenate $B$ with collagenase $(100 \mathrm{U} / \mathrm{ml})$, homogenate $C$ with heparinase $(5 \mathrm{U} / \mathrm{ml})$ and homogenate $\mathrm{D}$ with chondroitinase $A B C(6 \mathrm{U} / \mathrm{ml})$.

The control, $\beta$-mercaptoethanol-treated and enzyme-treated homogenates were incubated at $37^{\circ} \mathrm{C}$ for $18 \mathrm{~h}$ with occasional shaking and submitted to centrifugation at 12000 r.p.m. for $30 \mathrm{~min}$ at $4^{\circ} \mathrm{C}$. Supernatants (referred to as extracts) were collected and used for further studies. Those containing $\beta$ mercaptoethanol were dialysed against corresponding buffers (without $\beta$-mercaptoethanol) to remove the reducing agent.

The amounts of aFGF and bFGF extracted with the buffer: A, B, C and D were compared with those extracted with the same buffers supplemented 
with $\beta$-mercaptoethanol or a hydrolytic enzyme: hyaluronidase, collagenase, heparinase or chondroitinase.

Determination of aFGF and bFGF in the extracts. The concentrations of aFGF and bFGF in the extracts were assayed by an enzyme-linked immunoassay (ELISA) according to instructions provided by the manufacturer (R\&D).

Sodium dodecyl sulphate/polyacrylamide gel electrophoresis (SDS/PAGE). Slab SDS/PAGE was performed according to the method of Laemmli (1970) with $10 \%$ polyacrylamide gels. The samples (20 $\mu \mathrm{l})$ were applied to the gel and the apparent molecular mass was recorded relative to the Bio-Rad molecular mass standards of 207, 120, 92, 55.9, 34.5, 29 and $21 \mathrm{kDa}$.

Western immunoblot to detect aFGF, bFGF and FGF RII. After SDS/PAGE the gels were allowed to equilibrate in a mixture of $25 \mathrm{mM}$ Tris and 0.2 M glycine in $20 \%$ (v/v) methanol for $5 \mathrm{~min}$. Proteins were transferred to $0.2 \mu \mathrm{m}$ pore-sized nitrocellulose, at $250 \mathrm{~mA}$ for $1 \mathrm{~h}$ using a Bio-Rad Mini Trans-Blot ${ }^{\circledR}$ Cell MiniPROTEAN ${ }^{\circledR} 3$ electrophoresis unit. Nitrocellulose was blocked with $5 \%$ non-fat milk in TBS-T (50 mM Tris, $0.5 \mathrm{M} \mathrm{NaCl}, 0.05 \%$ Tween 20, pH 7.4) for $1 \mathrm{~h}$ at room temperature and probed with monoclonal antibodies to detect aFGF, bFGF and FGFR1 (Hossenlopp et al., 1986).

Activation of matrix metalloproteinases (MMPs). To investigate the influence of MMPs on the extraction of FGF, $600 \mathrm{mg}$ of tissue was suspended in $6 \mathrm{ml}$ of collagenase buffer (solvent B without inhibitors of proteolytic enzymes) and homogenised as described in Methods. The homogenate B was divided into three equal parts. The first was immediately centrifuged at 12000 r.p.m. for $30 \mathrm{~min}$ at $4^{\circ} \mathrm{C}$ and the supernatant was frozen at $-20^{\circ} \mathrm{C}$ until used as a control. The second was incubated at $37^{\circ} \mathrm{C}$ for $18 \mathrm{~h}$ with occasional shaking. The third was supplemented with $2 \mathrm{mM}$ aminophenylmercuric acetate (APMA) in order to activate MMPs and incubated under the same conditions. After incubation both homogenates were centrifuged at 12000 r.p.m., for $30 \mathrm{~min}$, at $4^{\circ} \mathrm{C}$. Each supernatant was collected and used for further studies.

Zymography. The procedure for zymography of gelatinase activity was based on a modification of the method of Hibbs et al. (1985). Each extract containing $20 \mu \mathrm{g}$ of protein was applied to $1 \%$ SDS, $10 \%$ polyacrylamide gel containing gelatin at $1.5 \mathrm{mg} / \mathrm{ml}$. Electrophoresis was run under non-reducing conditions at a constant voltage of $150 \mathrm{~V}$. After electrophoresis SDS was removed by incubation in a solution containing $2 \%$ Triton $\mathrm{X}-100$ at $37^{\circ} \mathrm{C}$ for $30 \mathrm{~min}$. The gel was then transferred into $0.05 \mathrm{M}$ Tris/ $\mathrm{HCl}$ buffer ( $\mathrm{pH}$ 8.0) containing $5 \mathrm{mM} \mathrm{CaCl}_{2}$, incubated at $37^{\circ} \mathrm{C}$ for $18 \mathrm{~h}$ and stained with $1 \%$ Coomassie Brilliant Blue R-250.

Statistical analysis. Mean values from 10 assays \pm standard deviations (S.D.) were calculated using statistical analysis with the Student's $t$-test, accepting $P<0.05$ as significant.

\section{RESULTS}

Figure 1 shows that the amount of aFGF extracted from Wharton's jelly depended on the composition of extracting solution. Solvent A without hyaluronidase extracted about $0.5 \mathrm{ng}$ of aFGF from $1 \mathrm{~g}$ of Wharton's jelly whereas the presence of hyaluronidase increased the amount of extractable aFGF to about $2.5 \mathrm{ng}$ per gram of tissue. The presence of $\beta$-mercaptoethanol exerted a similar (even slightly higher) effect (Fig. 1).

Significantly more aFGF ( $>15 \mathrm{ng}$ per $\mathrm{g}$ of tissue) was extracted by solvents $B$ and $C$ and these amounts were not significantly affected by the presence of collagenase or heparinase in the extracting solutions. However, the presence of $\beta$-mercaptoethanol in both solvents increased the extractability of aFGF, especially in solution C.

Solvent D extracted about $5 \mathrm{ng}$ of aFGF from $1 \mathrm{~g}$ of tissue and this was not affected by the presence of chondroitinase $A B C$ but the presence of $\beta$ mercaptoethanol resulted in a two-fold increase of aFGF extractability.

The extractability of bFGF also depended on the composition of the extracting solutions (Fig. 2). Solvent A failed to extract even a trace amount of bFGF and treatments with hyaluronidase or $\beta$-mercaptoethanol did not affect the bFGF extractability. Solvent B extracted more than $20 \mathrm{ng}$ of bFGF from $1 \mathrm{~g}$ of Wharton's jelly and this amount more than

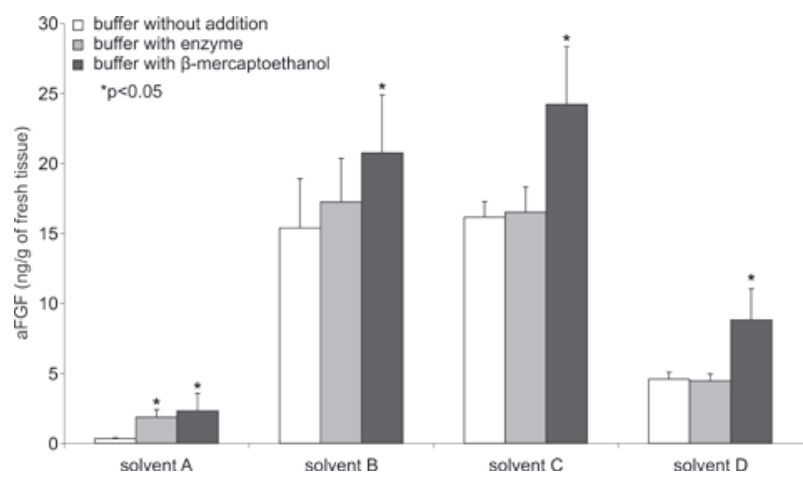

Figure 1. Extractability of aFGF from Wharton's jelly. Extractability with plain buffers and buffers supplemented with those treated with $\beta$-mercaptoethanol and with hydrolytic enzymes: hyaluronidase (solvent A), collagenase (solvent B), heparinase (solvent C) and chondroitinase (solvent D) is compared. Mean from 10 samples \pm S.D. 


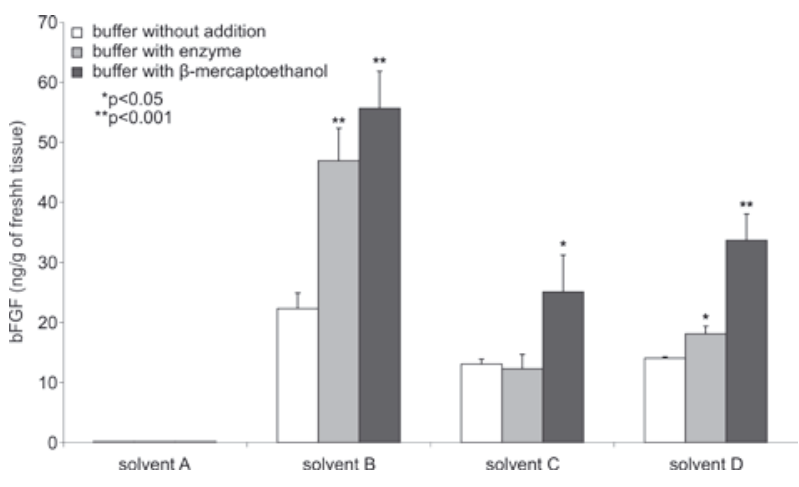

Figure 2. Extractability of bFGF from Wharton's jelly. Extractability with plain buffers and buffers supplemented with those treated with $\beta$-mercaptoethanol and with hydrolytic enzymes: hyaluronidase (solvent A), collagenase (solvent B), heparinase (solvent C) and chondroitinase (solvent D) is compared. Mean from 10 samples \pm S.D.

doubled under the action of collagenase, whereas in the presence of $\beta$-mercaptoethanol an almost 3 -fold increase in bFGF extractability was observed.

Solvents C and D extracted about $12 \mathrm{ng}$ of bFGF, with heparinase having no affect on the extractability of bFGF and chondroitinase $\mathrm{ABC}$ exerting only a slight (but statistically significant) increasing effect. The presence of $\beta$-mercaptoethanol in solvent $C$ almost doubled the bFGF extraction, whereas in solvent $\mathrm{D}$ more than twice the amount of bFGF was extracted compared to solvent D alone (Fig. 2).

SDS/PAGE followed by Western immunoblotting did not detect free FGFs. Figure 3 shows that aFGF extracted from Wharton's jelly hardly penetrated the polyacrylamide gel, but the action of $\beta$ mercaptoethanol reduced this high molecular mass substance to a band of a molecular mass of about 30 $\mathrm{kDa}$. Furthermore, a band (probably a dimer) corresponding to about $60 \mathrm{kDa}$ appeared.

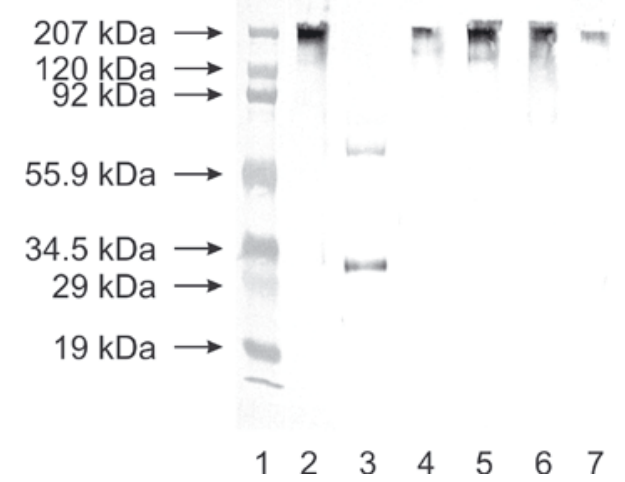

Figure 3. Western immunoblot analysis for aFGF in extracts of Wharton's jelly.

Lane 1, protein molecular mass standard; 2, extract without $\beta$-mercaptoethanol; lane 3 , extract with $\beta$-mercaptoethanol; lane 4, extract with hyaluronidase; lane 5, extract with collagenase; lane 6, extract with heparinase; lane 7, extract with chondroitinase. Samples of $20 \mu \mathrm{l}$ were run in each lane.

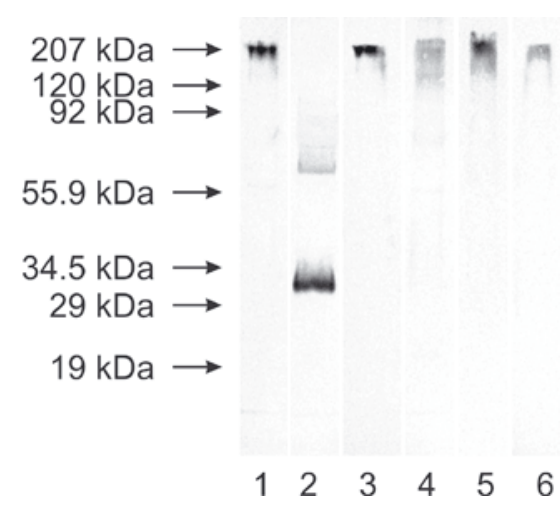

Figure 4. Western immunoblot analysis for bFGF in extracts of Wharton's jelly.

Lane 1, extract without $\beta$-mercaptoethanol; lane 2, extract with $\beta$-mercaptoethanol; lane 3 , extract with hyaluronidase; lane 4, extract with collagenase; lane 5, extract with heparinase; lane 6, extract with chondroitinase. Samples of $20 \mu \mathrm{l}$ were run in each lane.

In contrast to $\beta$-mercaptoethanol, the actions of hyaluronidase, collagenase, heparinase, and chondroitinase $\mathrm{ABC}$ did not exert any effect on the electrophoretic mobility of the protein reacting with the anti-aFGF antibody. In no case was a band corresponding to free aFGF detected.

Figure 4 shows that the extracts treated with $\beta$-mercaptoethanol together with the above mentioned enzymes produced an electrophoretic pattern for bFGF very similar to those observed in the case of aFGF. The treatment with $\beta$-mercaptoethanol resulted in the appearance of a $34 \mathrm{kDa}$ band, but the various enzyme treatments did not affect the electrophoretic pattern of bFGF extracted from Wharton's jelly.

SDS/PAGE followed by Western immunoblotting demonstrated that the extracts of Wharton's jel-

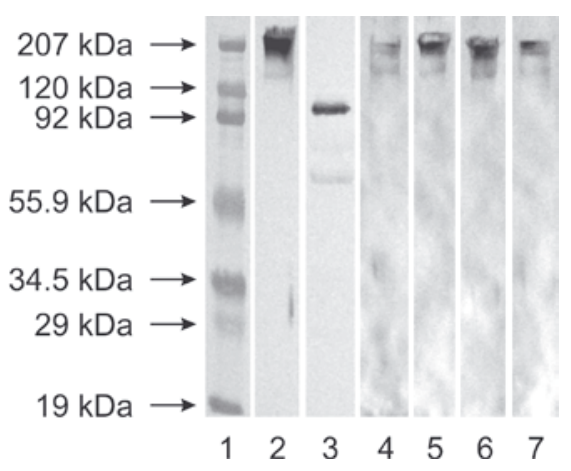

Figure 5. Western immunoblot analysis for FGFR-1 in extracts of Wharton's jelly.

Lane 1, protein molecular mass standard; 2, extract without $\beta$-mercaptoethanol; lane 3 , extract with $\beta$-mercaptoethanol; lane 4, extract with hyaluronidase; lane 5, extract with collagenase; lane 6, extract with heparinase; lane 7, extract with chondroitinase. Samples of $20 \mu \mathrm{l}$ were run in each lane. 


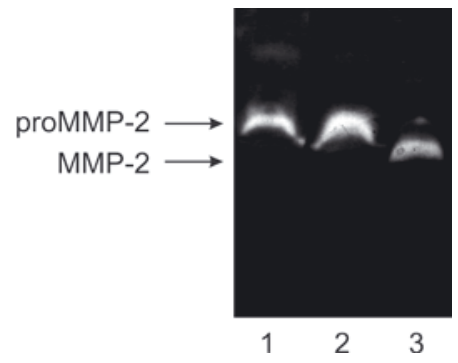

Figure 6. Zymography of Wharton's jelly extracts. Lane 1, control extract; lane 2, incubated extract; 3, extract incubated with APMA. Samples of $20 \mu \mathrm{l}$ were run in each lane.

ly contained the FGFR1 receptor (Fig. 5). The protein bands which reacted with the anti-FGFR1 antibody corresponded to a molecular mass of about $207 \mathrm{kDa}$, but the reducing action of $\beta$-mercaptoethanol resulted in the appearance of a band of about $100 \mathrm{kDa}$ which corresponded to free FGFR1. The enzymes degrading extracellular matrix components did not affect the electrophoretic pattern of FGFR1 extracted from Wharton's jelly.

Gelatin zymography of the extract of Wharton's jelly (Fig. 6) demonstrated the presence of matrix metalloproteinase-2 precursor form (proMMP-2) and conditions described in Materials and Methods seemed to intensify the band corresponding to this enzyme. The addition of APMA to the incubation mixture resulted in the appearance of a lower molecular mass band corresponding to the active form of MMP-2, in parallel to the disappearance of the proMMP-2 band.

Figure 7 shows that incubation of the homogenate in collagenase buffer resulted in a slight, but statistically significant, increase in aFGF extractability. At the same time the extractability of bFGF did not change. The activation of MMPs with APMA re-

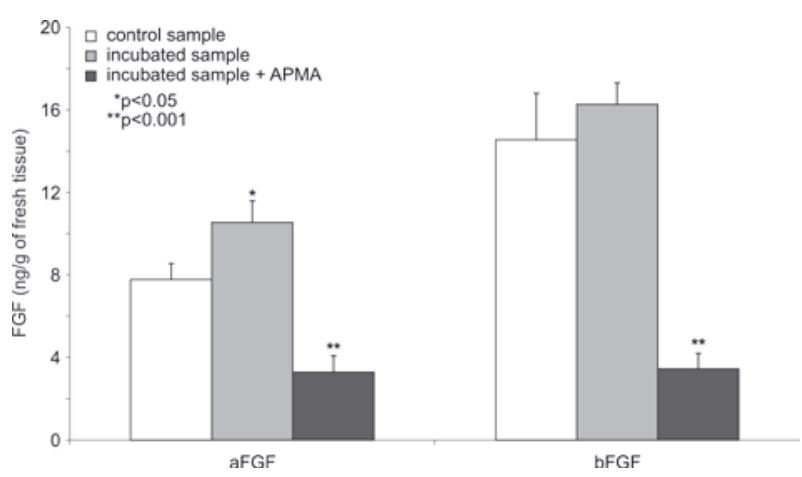

Figure 7. Extractability of aFGF and bFGF from homogenates of Wharton's jelly.

Extractability with non-incubated, incubated in collagenase buffer and from those activated with APMA is compared. Mean from 10 samples \pm S.D. sulted in a distinct decrease of both aFGF and bFGF contents in the extract.

\section{DISCUSSION}

The extracellular matrix is known to contain various growth factors which are bound and immobilized (Carey, 1997; Iozzo, 1998). Since aFGF and bFGF extracted from Wharton's hardly penetrate the polyacrylamide gel during SDS/PAGE it may be expected that these growth factors are bound to high molecular mass compounds, most probably some extracellular matrix components. Such complexes were very stable and did not dissociate under denaturing conditions, despite the action of high temperature $\left(100^{\circ} \mathrm{C}\right)$ and sodium dodecyl sulphate.

Heparan sulphate and heparin are known as the main FGF-binding components (Jackson et al., 1991; Tanaka et al., 1998) which may protect FGF against proteolysis and allow local concentrations of this factor in the vicinity of cells (Gallagher, 1996; Tanaka et al., 1998).

Enzymatic degradation of some extracellular matrix components significantly increased the extractability of FGFs. For example, the degradation of hyaluronate by hyaluronidase increased aFGF extractability, whereas hydrolysis of collagen by collagenase significantly increased the extractability of bFGF. The effect of degradation by chondroitinase $A B C$ evoked a similar but weaker effect. However, the action of any of these enzymes did not release free FGFs from the high molecular mass complexes.

This study has showed that the high molecular mass complexes containing the growth factor, which hardly penetrated the polyacrylamide gel, distinctly decreased in molecular mass under the reducing action of $\beta$-mercaptoethanol. This observation suggests that disulphide bonds are involved in the binding of aFGF and bFGF by protein(s) contained in the extracellular matrix of Wharton's jelly.

However, we remain doubtful whether the action of $\beta$-mercaptoethanol releases aFGF and bFGF in their free forms since the molecular masses of the products reacting with anti-aFGF and anti-bFGF antibodies seem to be double those of free aFGF and bFGF (Ornitz \& Itoh, 2001). Therefore we cannot exclude the possibility that Wharton's jelly contains isoforms (e.g., highly glycosylated) of these growth factors of a higher molecular mass.

The reason why digestion of Wharton's jelly by bacterial collagenase increased the extractability of bFGF is uncertain since it is unlikely that collagen binds bFGF (Taipale \& Keski-Oja, 1997). The effect of hyaluronidase and chondroitinase $\mathrm{ABC}$, although not impressive, was statistically significant. 
Wharton's jelly contains a low number of cells which are irregularly scattered and surrounded by a ground substance composed mainly of collagen fibrils and hyaluronate molecules (Sobolewski et al., 1997). The hyaluronate, chondroitin sulphates and collagen of Wharton's jelly may prevent the access of extracting solution to FGFs, thereby causing a low extractability of these factors. It therefore seemed likely that the degradation of these extracellular matrix components by hyaluronidase, collagenase, or chondroitinase might enhance the extractability of FGFs.

Although hyaluronate and collagen do not bind FGFs directly, they may constitute a barrier which effectively concentrates the FGFs in Wharton's jelly around the cells and their membrane receptors. Thus, the action of hyaluronidase and collagenolytic MMPs may disrupt such a barrier and allow the contact of FGFs with cell membrane receptors.

The activation of metalloproteinases by APMA resulted in a distinct decrease of the aFGF and bFGF contents of Wharton's jelly. According to Overall (2002), MMPs are able to degrade some noncollagenous components of the extracellular matrix, and possibly those which form complexes with FGFs, thus the FGFs released from such complexes may be digested by various proteolytic enzymes.

The binding of FGFs in the vicinity of cells of Wharton's jelly is a very important biological phenomenon since it has recently been reported (Mitchell et al., 2003; Weiss et al., 2003; Wang et al., 2004) that the fibroblast-like cells contained in this tissue demonstrate the features of stem cells. Under the action of bFGF they are able to transform into neuron cells or glia cells (Mitchell et al., 2003; Ma et al., 2005) and xenotransplantation of such cells may reverse some symptoms of experimental Parkinson's disease in rats (Weiss et al., 2006).

Changes in the composition the extracellular matrix of Wharton's jelly during some pathological conditions, like pre-eclampsia (Bańkowski et al., 1996) or Down syndrome (Raio et al., 2005), may alter the accessibility of FGFs to the cells. Since these growth factors act mainly through an autocrine or paracrine manner, the high concentration of FGFs in the vicinity of cells may facilitate their interaction with membrane receptors resulting in the stimulation of cell division and synthesis of extracellular matrix components.

\section{Acknowledgements}

This work was supported by the Ministry of Scientific Research and Information Technology, grant No. 3 P05E 04223.

\section{REFERENCES}

Bańkowski E, Sobolewski K, Romanowicz L, Chyczewski L, Jaworski S (1996) Collagen and glycosaminoglycans of Wharton's jelly and their alterations in EPH-gestosis. Eur J Obstet Gynecol Reprod Biol 66: 109-117.

Carey DJ (1997) Syndecans: multifunctional cell-surface co-receptors. Biochem J 327: 1-16.

Edmondson SR, Thumiger SP, Werther GA, Wraight CJ (2003) Epidermal homeostasis: the role of the growth hormone and insulin-like growth factor systems. Endocrine Rev 24: 737-764.

Franc S, Rousseau JC, Garrone R, van der Rest M, MoradiAmeli M (1998) Microfibrilar composition of umbilical cord matrix: characterization of fibrillin, collagen VI and intact collagen V. Placenta 19: 95-104.

Gallagher JT (1996) Heparan sulphate proteoglycans. The control of cell growth. In Extracellular Matrix 2 (Comper WD, eds) pp 230-245. Amsterdam: Harwood Academic Publishers GmbH.

Hibbs MS, Hasty KA, Seyer JM, Kang AH, Mainardi CL (1985) Biochemical and immunological characterization of secreted forms of human neutrophil gelatinase. J Biol Chem 260: 2493-2500.

Hossenlopp P, Seurin D, Segovia-Quinson B, Hardouin S, Binoux M (1986) Analysis of serum insulin insulin-like growth factor binding proteins using Western blotting; use of the method for titration of the binding proteins and competitive binding studies. Anal Biochem 154: 138-143.

Iozzo RV (1998) Matrix proteoglycans: from molecular design to cellular function. Annu Rev Biochem 67: 609652.

Jackson RL, Busch SJ, Cardin AD (1991) Glycosaminoglycans: molecular properties, protein interaction, and role in physiological processes. Physiol Rev 71: 481525.

Kobayashi K, Kubota T, Aso T (1998) Study on myofibroblasts differentiation in the stroma cells of Wharton's jelly: expression and localization of $\alpha$-smooth muscle actin. Early Human Dev 3: 223-233.

Laemmli UK (1970) Cleavage of structural proteins during the assembly of the head of bacteriophage T4. Nature 227: 680-685.

Ma L, Feng XY, Cui BL, Law F, Jiang XW, Yang LY, Xie QD, Huang TH (2005) Human umbilical cord Wharton's jelly-derived mesenchymal stem cells differentiation into nerve-like cells. Chin Med J 118: 1987-1993.

Mitchell KE, Weiss ML, Mitchell BM, Martin P, Davis D, Morales L, Helwig B, Beerenstrauch M, Abou-Easa K, Hildreth T, Troyer D, Medicetty S (2003) Matrix cells from Wharton's jelly form neurons and glia. Stem Cells 21: $50-60$.

Ornitz DM, Itoh N (2001) Fibroblast growth factors. Genome Biology 2: reviews3005.1-12.

Overall CM (2002) Molecular determinants of metalloproteinase substrate specificity: matrix metalloproteinase substrate binding domains, modules, and exosites. Mol Biotechnol 22: 51-86.

Raio L, Cromi A, Ghezzi F, Passi A, Karousou E, Viola M, Vigetti D, De Luca G, Bolis P (2005) Hyaluronan content of Wharton's jelly in healthy and Down syndrome fetuses. Matrix Biol 24: 166-174.

Shalitin N, Schlesinger H, Levy MJ, Kessler E, KesslerIcekson G (2003) Expression of procollagen C-proteinase enhancer in cultured rat heart fibroblasts: evidence for coregulation with type I collagen. J Cell Biochem 90: 397-407. 
Sobolewski K, Bańkowski E, Chyczewski L, Jaworski S (1997) Collagen and glycosaminoglycans of Wharton's jelly. Biol Neonate 71: 11-21.

Sobolewski K, Małkowski A, Bańkowski E, Jaworski S (2005) Wharton's jelly as a reservoir of peptide growth factors. Placenta 26: 747-752.

Taipale J, Keski-Oja J (1997) Growth factors in the extracellular matrix. FASEB J 11: 51-59.

Takechi K, Kuwabara Y, Mizuno M (1993) Ultrastructural and immunohistochemical studies of Wharton's of jelly umbilical cord cells. Placenta 14: 235-245.

Tanaka Y, Kimata K, Adams DH, Eto S (1998) Modulation of cytokine function by heparin sulfate proteoglycans: sophisticated models for the regulation of cellular responses to cytokines. Proc Assoc Am Physicians 110: 118-125.

Wang HS, Hung CS, Peng ST, Huang CC, Wei HM Guo YJ, Fu YS, Lai MC, Chen CC (2004) Mesenchymal stem cells in the Wharton's jelly of the human umbilical cord. Stem Cells 22: 1330-1337.

Weiss ML, Mitchell KE, Hix JE, Medicetty S, El-Zarkouny SZ, Grieger D, Troyer DL (2003) Transplantation of porcine umbilical cord matrix cells into the brain. Exp Neurol 182: 288-299.

Weiss ML, Medicetty S, Bledsoe AR, Rachakatla RS, Choi M, Merchav S, Luo Y, Rao MS, Velagaleti G, Troyer D (2006) Human umbilical cord matrix stem cells: preliminary characterization and effect of transplantation in a rodent model of Parkinson's disease. Stem Cells 24: 781-792.

Yu C, Wang F, Jin C, Huang X, Miller DL, Basilico C, McKeehan WL (2003) Role of fibroblast growth factor type 1 and 2 in carbon tetrachloride-induced hepatic injury and fibrogensesis. Am J Pathol 163: 1653-1662. 